\title{
The Study of Factors Affecting the Vietnamese Consumer's Intention to Write Referrals on Facebook
}

\author{
Thi Thanh Mai NGUYEN ${ }^{*}$, Hoang Minh DOAN² and Hong Hoa PHAM ${ }^{3}$ \\ ${ }^{1}$ Economic Research Institute of Posts and Telecommunications, Posts and Telecommunications Institute of Technology, \\ Hanoi, Vietnam \\ ${ }^{2}$ Faculty of Marketing, National Economics University, Hanoi, Vietnam \\ ${ }^{3}$ Faculty of Marketing, National Economics University, Hanoi, Vietnam \\ *Corresponding author: nguyenthithanhmai.dnu@gmail.com
}

\begin{abstract}
Referrals on social networks, especially on Facebook, have a great impact on consumers, businesses and communities. Many fake referrals are now spreading on Facebook causing many damages. Thus, it is important to identify the internal factors of each individual, especially those related to personal awarenesss or responsibility affecting the intention to write real referrals of consumer. The main objective of this study is to explore the internal factors of each individual that influence this type of intention. From the data obtained from 505 survey questionnaires, the author has performed descriptive statistical methods of the sample, tested the reliability of the scale by Cronbach's Alpha coefficient, performed exploratory factor analysis (EFA) and multiple regression analysis. The research results show that there are four main factors affecting the Vietnamese consumer's intention to write referrals on Facebook: ascription of responsibility, ego involvement, perceived behavioral control and subjective norm. Research results, limitations and future research prospects will also be discussed in this paper.
\end{abstract}

\section{Research purpose:}

Explore and test the internal factors affecting the intention to write referrals on Facebook of Vietnamese consumers.

\section{Research motivation:}

Promote the consumer's behavior of writing real referrals on Facebook that could provide positive benefits to consumers, businesses and communities and minimize appearance and spread of fake referrals that cause damages for them.

Research design, approach and method:

Use convenience random sampling method. Data from 505 questionnaires were processed and analyzed.

Use descriptive statistical method, test of the reliability of the scale by Cronbach's Alpha, exploratory factor analysis (EFA) and multiple regression analysis.

\section{Main findings:}

Identify four main internal factors affecting the Vietnamese consumer's intention to write referrals on Facebook: ascription of responsibility, ego involvement, perceived behavioral control and subjective norm.

\section{Practical/managerial implications:}

Prioritize creating favorable conditions to promote this tendency of ascription of responsibility and ego involvement of customers. Target potential customers and their important reference groups. Simplify writing referrals process for customers

Keywords: Referrals on Facebook, behavioral intention of vietnamese consumer on Facebook, pro-social behavior, norm activation model, ego involvement, ascription of responsibility. 


\section{INTRODUCTION}

User-generated referrals about product and service are proven to have a strong impact on consumer buying behavior in practice and in research papers. Sorensen and Rasmussen (2004) have investigated the results of the New York Times (NYT) assessment that referrals will be on the internet platform (on the website or on social media) have a positive impact on sales. According to a survey by Sheraton (2010), 76\% of people have used social networks to collect information when planning travel, of which, $92 \%$ of users read product reviews and $89 \%$ of them recognized that good product reviews have an impact on motivating them to choose products/services (Dixit et al., 2019). With the development of the internet, especially of social network, consumer referrals become easier and more convenient. On social network, referral content can be presented in many different forms: text, images, videos, links. Referrals are delivered quickly and on a large scale. Referrals on social network allow access to large numbers of other consumers helping the referral content to reach hundreds of thousands, even millions of users (Cakim, 2009; Sohn, 2014) at a rapid pace (Huang et al., 2011;). Among social network platforms, Facebook is considered the most popular and developed platform. In Vietnam, Facebook is the most popular social network with more than 73 million accounts (according to Napoleoncat's statistics in February 2021) ${ }^{1}$. Vietnamese consumers often search information about product/service on Facebook and perform many shopping on this social network. The explosive growth of this platform has significantly changed commerce, marketing and consumer behavior (Nambisan and Baron, 2007; Wang et al., 2012). Many people often write referrals about product/service for others on Facebook. These referrals provide valuable references supporting other consumers in making purchasing decisions. It is the consumer's dependence on social network that drives their interaction on the platform (Banerjee, 1992). Referrals on social network have a direct and indirect impact on consumers' purchase intention and indirectly promote business sales (Kim and Kim, 2018) and increase business brand equity (Yan et al., 2019). As mentioned above, vietnamese consumers regularly make shopping on Facebook. Referrals on Facebook will have a direct impact on their buying behavior and at the same time, impact on sales and brand of the business. Therefore, it is necessary to understand the factors affecting the intention to write referrals of consumers on Facebook. Especially, in the context of an increasing number of fake referrals, damaging the interests of consumers, businesses and the community, the internal factors related to personal awareness and responsibility affect the intention to write referrals on Facebook of individual consumers should be included in the study. Theory of planned behavior (TPB) of Ajzen (1991) states that people's behavior is the result of their intention to perform the behavior. Thus, behavioral intention is an

\footnotetext{
${ }^{1}$ https://napoleoncat.com/stats/facebook-users-in-viet_nam/2021/02
}

important antecedent of behavior. Therefore, this article studies intention instead of behavior of write referrals. Understanding the internal factors affecting the intention to write referrals on Facebook not only promote and spread useful information from real referrals, but also minimize fake referrals spreading on this social network.

\subsection{Literature reviews}

Referral is the act of directing someone to a different place or person for information, help, or action, often to a person or group with more knowledge or power (Cambridge Dictionary). In marketing, referrals are understood as referrals between customers. This is mentioned in the studies of Shao (2014). He calls it customer referrals. In the study of Godes et al. (2005), referral is also understood as the social interaction between consumers and based on their personal opinions. Therefore, in this study, we focus on referrals between consumers. Referrals by businesses, or paid by businesses, were not considered in this study. For the same reason, referrals from KOLs (Key opinion leader) were outside the scope of the study. Accordingly, writing referrals about product/service on Facebook is the behavior performed by consumers on Facebook, introducing others to good product/service with the desire to bring certain benefits to others. Unlike on e-commerce sites, referrals on Facebook are aimed at acquaintances because Facebook is a connection platform for people who have more or less contact with users (friends, colleagues, etc.). In fact, more than $90 \%$ of consumers often trust referrals on social network, and only about $70 \%$ of users trust referrals from unknown people Dixit et al.., 2019). Thus, referrals on social network of consumer are the most trusted form of advertising for their friends and relatives (Nielsen, 2012). Referrals of consumer can help other consumers find the most suitable product for them because these referrals are often based on consumer's personal experience (Zhou and Duan, 2016). Some studies also prove that when writing referrals on social networks, writers have several psychological motives: desire of helping other consumers; or creating personal reputation (Hennig Thurau et al., 2002). Therefore, researchers have also suggested that through writing referrals, consumer can both create and receive social value (Larbrecque et al., 2013). Thus, writing referrals on social network not only bring benefits to the writer, but also can bring values to society.

Previous studies have provided ample evidences for the effects of referrals on consumer behavior. However, the research literature on the internal factors predicting the intention to write referrals is still limited, especially in contexte of Vietnam. In addition, as mentioned above, referrals have an impact motivating consumers to choose products and services Dixit et al.., 2019). And especially in service areas such as tourism, hotels, restaurants, etc., referrals on social network play an important role in influencing the number of customers accessing the company's services. Therefore, understanding these factors can bring many benefits to marketers. Because of 
the scarcity of studies for this context, the present study focused on identifying the factors that predict the intention to write referrals on the most popular social network_Facebook. This study could be pioneering research in the Vietnamese market, potentially spurring relevant research efforts in the Vietnamese market.

In this study, authors consider writing referrals on Facebook as a pro-social behavior because it brings benefits to other consumers (providing information to support purchasing decisions), to the community (enriching online knowledge shared and spread on social networks). In previous studies, an individual's pro-social behavior was explained by two main motivations: personal motivation and social motivation (Han, Lee and Hwang, 2016; Harland et al., 1999). For individual motivation, the most commonly applied underlying theory to predict a pro-social behavior is the theory of planned behavior (TPB) of Azjen (1991) (Han et al., 2016). And social motivation is explained in previous studies by the norm activation model (NAM) of Schwartz (1977). The NAM model is a popular model used in previous studies to examine the role of pro-social motivation in consumers' socially responsible decision-making (Han, 2014; Harland et al., 2007). A research model based on the factors of these two theoretical models allows a comprehensive assessment of both personal and social aspects of individual pro-social behavior.

\subsection{Theoretical models related to the study of intention to write referrals}

\section{Theory of planned behavior (TPB)}

The theory of planned behavior (TPB) of Ajzen (1991) is a typical model, most widely applied in the study of the intention or behavioral intention of individuals. The TPB model was originally proposed by Ajzen (1985) on the basis of the dynamic theory of rational action TRA of Fishbein \& Ajzen (1975). According to this model, an individual's behavior derives from their behavioral intentions; and behavioral intention is determined from three influencing factors: attitude towards behavior, subjective norm and perceived behavioral control (Ajzen, 1991). Accordingly, attitude towards behavior is understood as an individual's assessment of the degree of favorability or unfavorableness towards the behavior; subjective norm is defined as an individual's perception of social pressures that promote or limit behavior; Perceived behavioral control refers to the advantages and disadvantages that individuals perceive when performing a behavior (Ajzen, 1991)

The TPB model has been proven in many studies to be a model that allows successful prediction of behaviors in many different contexts (Ajzen and Driver, Han and Kim, 2010; Han et al., 2010; Lam et al. Hsu, 2004, 2006). In particular, this model is also used in studies of similar behaviors to writing referrals on Facebook such as: electronic word of mouth (Cheng et al., 2006) and the use of online referrals when making decisions. (Fogel and
Zachariah, 2017; Wang, 2014; Jalilvand and Samiei, 2012).

\section{Norm Activation Model (NAM)}

The norm activation model (NAM) of Schwartz (1977) is the model applied in research on altruistic behavior. The NAM model examines the factors that activate personal norm, which in turn motivate individuals to perform a certain pro-social behavior (Schwartz, 1977). Schwartz (1977) argues that an individual's pro-social behavior or intention is affected by personal norm (PN), awareness of consequences (AC) and ascription of responsibility (AR). In this model, AC is defined as an individual's perception of negative consequences for others or for other things one values when not actively performing a altruistic behavior; AR refers to individual's senses of responsibility for the negative consequences of not engaging in altruistic behavior; and $\mathrm{PN}$ indicates individual's sense of a moral obligation to perform or refrain from specific altruistic actions. This model explores the sequential process that stems from awareness of consequences through ascription of responsibility and then activates personal values and norm, which directly influence pro-social behavior (De Groot \& Steg et al., 2009; Steg \& De Groot, 2010). Accordingly, when an individual perceives the possible consequences for others and for society if the behavior is not performed (AC), he will activate their sense of responsibility for these negative consequences (Schwartz, 1977) and then his personal norm will be activated. It means that his moral obligation motivates him to perform or to refrain specific pro-social behaviors (Schwartz and Howard, 1981).

The NAM model is widely used for environmental, psychological behavior studies to determine the effects of personal norm on behavior and is one of the most prominent theories in the study of altruistic: bone marrow donation (Schwartz, 1970, 1973), blood donation (Zuckerman and Reis, 1978), volunteering (Schwartz and Fleishman, 1982; Schwartz and Howard, 1980), and helping in emergencies (Schwartz and Clausen, 1970; Schwartz and David, 1976); conservation of energy (Black, Stern, and Elworth, 1985; Tyler, Orwin, and Schurer, 1982). It can be said that the NAM model is a one of the most prominent theories in the study of socially responsible behaviors of individuals (Schwartz, 1977; Steg and De Groot, 2010; Zhang et al., 2013).

\subsection{Proposed research model and hypotheses}

Attitude towards behavior is defined as an individual's assessment of the degree of favorability or unfavorableness towards the behavior. This assessment, which can be positive or negative, will either promote or limit the intention to perform a certain behavior (Fishbein, 1979). Ajzen (1991) suggested that an individual with a favorable attitude towards the behavior will promote a stronger intention to perform 
the behavior. And an individual who will strongly believe that performing the behavior will bring about positive results will have a positive attitude towards that behavior.In studies on behaviors that have some similar characteristics to the behavior of writing referrals on Facebook, attitudes (ATT) have also been shown to have an impact on behavior and behavioral intentions (intention to write an online review on the website by Picazo-Vela et al. (2010); intention to post content on Wikipedia by Park et al (2015), or electronic word of mouth by Cheng et al (2006)). Picazo-Vela et al. (2010) said that attitude is one of the important predictors of intention to write online reviews. On Facebook, individuals who have a positive attitude towards writing referrals on Faceboo can drive the intention to do this behavior. Thus, hypothesis $\mathrm{H} 1$ is as follows:

\section{H1: Attitude (ATT) is positively related to intention to write referrals on Facebook (INWR)}

Subjective norm (SNO) is understood as an individual's perception of the opinions (encouragement or disapproval) of those who are important to them when performing a certain behavior. Ajzen (1991) suggested that if a person perceives his significant other to be supportive of the behavior, they will be more inclined to perform the behavior and vice versa. Subjective norm is a factor that reflects an individual's perception of social pressures affecting an individual's behavior (De Groot and Steg, 2007). Ajzen (1991) also demonstrated that an individual with a large subjective norm promotes a stronger behavioral intention (Ajzen, 1991). On Facebook, where individuals are placed in relationships with many online friends, individuals having frequent and close interactions with other members can increase the intention of writing referrals. That can be explained by individuals' perception that writing referrals behavior has a higher chance of getting support and encouragement from the community due to their personal influence in this community. Furthermore, the individual's Facebook network includes strangers but mostly people who are close or related to the individual in the real world. It is this "familiarity" that makes individuals aware that their writing referrals are more likely to be encouraged. This is predicted to have an impact on intention of writing referrals. Therefore, hypothesis $\mathrm{H} 2$ is as follows:

\section{H2: Subjective norm (SNO) is positively related to intention to write referrals on Facebook (INWR)}

Perceived behavioral control (PEBC) is understood as an individual's perception of the advantages and disadvantages of performing a behavior. This is a factor that reflects an individual's perception of the ability to perform or not perform a certain behavior. PEBC refers to individuals' resources for behavior such as time, money, technical conditions, etc., as well as their level of confidence in their ability to perform the behavior (Ajzen and Fishbein, 2000; Wu et al., 2017). Ajzen
(1991) also asserted that an individual with a higher perceived behavioral control will have a stronger intention to perform the behavior (Ajzen, 1991). This study refers to the behavioral intention on Facebook which provides many features to its users. An individual who understands how to operate and use features on Facebook or how to write referrals in different forms (text, audio, images, video, ..) will be more confident when performing the behavior of writing referrals. Meanwhile, PEBC is understood as an individual's understanding of how to perform the behavior in a difficult or favorable way, including two factors, the ability to self-control and control (Ajzen, 1991; Park et al., 2015). In which, self-control represents an individual's confidence in performing a behavior (Bandura, 1997) and control is defined as an individual's assessment of the availability of resources when performing a behavior. Thus, knowledge about the social network Facebook or how to write referrals can be considered as factor PEBC. Therefore, hypothesis H3 is as follows:

H3: Perceived behavioral control (PEBC) is positively related to intention to write referrals on Facebook (INWR)

Ego involvement (EI) refers self-concept in a certain position in accordance with a certain role (Lapinski and Rimal, 2005), which is considered an important part of affirmation self-image of the individual (Perloff, 1989; Sherif et al., 1965). Individuals joining Facebook may be motivated by psychological motives such as fame and self-image (Buffardi and Campbel, 2008; Ryan and Xenos, 2011; Tennie et al., 2010). They perceive that writing referrals on Facebook can bring certain benefits such as increasing personal image (Cheshire, 2007). Facebook posts are visible to a large community (in friends and friends of friends), giving individuals an opportunity to brand their image. That can promote the intention to write referrals on Facebook. Thus, hypothesis $\mathrm{H} 4$ is as follows:

\section{H4: Ego involvement (EI) is positively related to intention to write referrals on Facebook (INWR)}

Awareness of consequences (AC) is defined as an individual's perception of negative consequences for others or with other values when not actively performing a certain behavior (Schwartz, 1977). This is a factor that indicates an individual's perception of negative consequences for others or the values others if he do not perform a pro-social behavior (De Groot and Steg, 2009). An individual who is aware of the negative consequences of not performing the behavior will tend to perform this behavior through the activation of the individual's personal norm (Schwartz, 1977). However, De Groot and Steg (2009) and Stern (2000) also agree that the awareness of consequences can affects responsibilities, personal norm and also directly affects behavioral intention. Therefore, the author hypothesizes 
H5 about the relationship between the two factors awareness of consequence (AC) and the intention to write referrals on Facebook (INWR) as follows:

H5: Consequence perception (AC) is positively related to intention to write referrals on Facebook (INWR)

Ascription of resposibility (AR) is defined as an individual's sense of responsibility for the negative consequences of not engaging in altruistic behavior (De Groont and Steg, 2009). With such a definition, it can be seen that both the awareness of consequence (AC) and ascriptionof respondibilitiy (AR) are related to the individual's perception and feelings for the negative consequences caused by not performing behavior. However, both factors can be placed independently and still show their relationship to other factors in the model. Furthermore, De Groot and Steg (2009) and Stern (2000) also suggest that ascription of resposibility (AR) can directly impact altruistic intentions. Hypothesis H6 is $\mathrm{s}$ as follows:

H6: Ascription of resposibility (AR) is positively related to intention to write referrals on Facebook (INWR)

With these hypotheses, research model and the regression equation are determined as follows:

$\mathbf{I N W R}=\beta_{0}+\beta_{1} * \mathbf{A T T}+\beta_{2} * \mathbf{S N O}+\beta_{3} * \mathbf{P E B C}+\beta_{4} * \mathbf{A C}+\beta_{5} * \mathbf{A R}+\beta_{6} * \mathbf{E I}$

- Dependent variable (INWR): Intention to write referrals on Facebook

- Independent variables: Attitude (ATT); Subjective norm (SNO); Perceived behavioral control (PEBC); Awareness of consequence(AC); Ascription of resposibility (AR); Ego involvement (EI)

- $\beta_{\mathrm{k}}$ : Regression coefficient $(\mathrm{k}=0,1,2, \ldots, 5)$

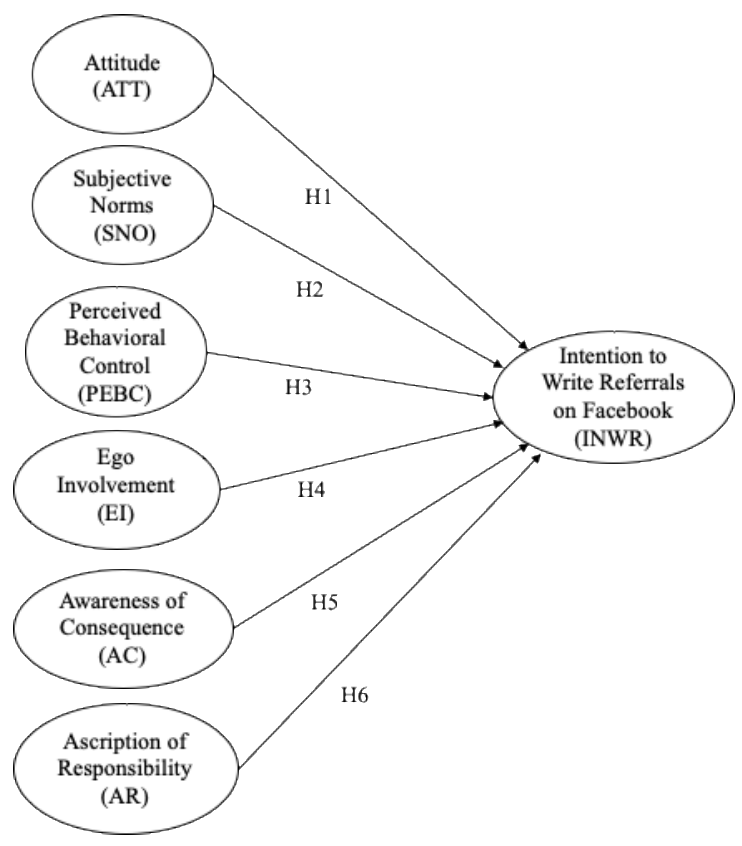

Fig. 1. Proposed conceptual model for predicting intention to write referrals on Facebook

\section{METHODOLOGY}

This study proposes a model that combines factors belonging to two theoretical models TPB and NAM, along with the participation factor of ego involvement (EI). The final questionnaire was adjusted to suit the context of this study and was preliminarily validated through two tests: a small qualitative research with 10 individuals and preliminary quantitative research with 110 questionnaires. As a result, a completed survey instrument for formal quantitative research have been developped, including sept sections to examine. Attitude (ATT), subjective norm (SNO) are measured by 5 items, perceived behavioral control (PEBC) is measured by 4 items. The items that measure these variables are inherited and adjusted from Ajzen (2002) and Park et al. (2015). Ego involvement (EI) was measured using 5 items, adjusted from Conner et al. (1999) and Park et al. (2015). Each of two variables awareness of consequences (AC) and ascription of responsibility (AR) is measured by 5 items, adjusted from De Groot and Steg (2009) and Han (2014); intention of write referrals on Facebook (INWR) is mesured by 5 items, adjusted from Ajzen (2002), Park et al. (2015) and Han (2014). All measurement items (Table 2) were answered on a five-point Likert-type scale, indicating the degree of agreement with the statements from strongly disagree to strongly agree.: Strongly disagree (1) - Disagree (2) Neutral (3) - Agree (4) - Strongly agree (5).

This study's target population is consumers living in Vietnam, aged 18 and over, who use Facebook for writing product/service referral (at least once). The survey is only for those who have written a referral on Facebook at least once. Those who answered "yes" to 
the question "Have you ever written referral on Facebook?" will be invited to continue answering the questionnaire. Out of 685 responses, 505 cleaned reponses have been used for data analysis. Descriptive statistics of the sample are presented in Table 1. The author used convenience random sampling method (by online questionnaires). Collected data were processed by SPSS 26.0 software. After filtering and coding, the data is analyzed by performing the following techniques and methods: descriptive statistics; Cronbach's Alpha coefficient, exploratory factor analysis (EFA) and multiple regression analysis. Cronbach's Alpha coefficient is used to eliminate bad variables (variables with total correlation coefficient less than 0.3 and Cronbach's Alpha coefficient less than 0.6) (H. Trong, C.N.M. Ngoc, 2008). EFA allows to exclude items with loading factor less than 0.5 and to be extracted into 2 factors with difference less than 0.3 (H. Trong, C.N.M. Ngoc, 2008). The Eigenvalue (representing the variation explained by each factor) is greater than 1 and the total variance extracted is greater than $50 \%$. Besides, KMO (Kaiser-Mayer-Olkin) and Bartlet test are used to evaluate the reasonableness of the data. The F-test in the analysis of variance table is used to test the hypothesis. When Sig. < 0.05, the regression model fits the data set and can be used. Before analyzing the regression equation, the author analyzed the Pearson correlation to check the close correlation between the dependent variable and the independent variables. VIF coefficient is also used to test the multicollinearity.

Table 1: Demographic Characteristics of the Respondents $(\mathrm{N}=505)$

\begin{tabular}{|c|c|c|}
\hline \multicolumn{3}{|c|}{ Gender } \\
\hline Category & Frequency & $\begin{array}{c}\text { Percentage } \\
(\%)\end{array}$ \\
\hline Male & 179 & 35.4 \\
\hline Female & 298 & 59.0 \\
\hline Others & 28 & 5.5 \\
\hline \multicolumn{3}{|c|}{ Age (in years) } \\
\hline $18-25$ & 99 & 19.6 \\
\hline $26-35$ & 172 & 34.1 \\
\hline $36-55$ & 196 & 38.8 \\
\hline Above 55 & 38 & 7.5 \\
\hline Education level \\
\hline High school & 58 & 11.5 \\
\hline
\end{tabular}

\begin{tabular}{|c|c|c|}
\hline $\begin{array}{l}\text { College in school, } \\
\text { College graduate }\end{array}$ & 273 & 54.1 \\
\hline Postgraduate & 174 & 34.5 \\
\hline \multicolumn{3}{|c|}{ Location of residency } \\
\hline Hanoi & 229 & 45.3 \\
\hline Ho Chi Minh city & 163 & 32.3 \\
\hline Others & 113 & 22.4 \\
\hline \multicolumn{3}{|c|}{ Allowance (income) per month (milion dongs } \\
\hline Less than 5 & 55 & 10.9 \\
\hline 5 to 10 & 106 & 21.0 \\
\hline 11 to 20 & 192 & 38.0 \\
\hline Above 20 & 152 & 30.1 \\
\hline Total & 505 & 100 \\
\hline
\end{tabular}

\section{RESULTS AND DISCUSSION}

\subsection{Descriptive statistics}

According to the results from Table 1, out of a total of 505 survey participants, the majority are female with 298 people $(59 \%)$. Most of the survey participants were between the ages of 26 and 55 years old (72.9\%). It can be seen that at this age, they are almost working people, earning income and are also educated people. Therefore, most of them have an average monthly income of between 11 million and over 20 million (68.1\%) and have intermediate or higher education level (88.6\%). Most of the collected surveys come from people living in two big cities, Hanoi (45.3\%) and Ho Chi Minh City $(32.3 \%)$. These two areas are considered as areas with a large number of consumers who regularly participate and buy goods on Facebook. The sample descriptive statistics results can be considered to match the author's sampling criteria for this study.

\subsection{Reliability of the scale}

Cronbach's alpha is used to measure internal consistency of the measurement scales. As the results tabulated in table 2, the values of Cronbach's Alpha of all constructs are greater than 0,8. All total correlation coefficient of variables have results greater than 0.3 . Cronbach's Alpha if Item Deleted are smaller than Cronbach's Alpha coefficient (Nunnally, 1978). These results show that the scale ensures the reliability for this study (Table 2) 
Table 2: Item measurement properties and results of Cronbach's Alpha test

\begin{tabular}{|c|c|c|c|c|}
\hline Construct & Item & $\begin{array}{l}\text { Cronbach's } \\
\text { Alpha }\end{array}$ & $\begin{array}{l}\text { Corrected } \\
\text { Item-Total } \\
\text { Correlation }\end{array}$ & $\begin{array}{l}\text { Cronbach's } \\
\text { Alpha if } \\
\text { Item } \\
\text { Deleted }\end{array}$ \\
\hline \multirow{5}{*}{$\begin{array}{l}\text { Attitude } \\
\text { (ATT) }\end{array}$} & ATT1: Write referrals on Facebook are helpful & .857 & 610 & .845 \\
\hline & ATT2: Write referrals on Facebook are important & & .701 & .819 \\
\hline & ATT3: Write referrals on Facebook are a good thing & & .730 & .813 \\
\hline & ATT4: Write referrals on Facebook is necessary & & .676 & .826 \\
\hline & $\begin{array}{l}\text { ATT5: Write referrals on Facebook bring positive } \\
\text { value }\end{array}$ & & .654 & .831 \\
\hline \multirow{5}{*}{$\begin{array}{l}\text { Subjective } \\
\text { norm (SNO) }\end{array}$} & $\begin{array}{l}\text { SNO1: Most of my important relatives and friends } \\
\text { on Facebook support me to write referrals on } \\
\text { Facebook }\end{array}$ & .864 & .674 & .838 \\
\hline & $\begin{array}{l}\text { SNO2: Most of my important relatives and friends } \\
\text { will read my referrals on Facebook }\end{array}$ & & .695 & .833 \\
\hline & $\begin{array}{l}\text { SNO3: Most of my important relatives and friends } \\
\text { will be satisfied if I write referrals on Facebook }\end{array}$ & & .720 & .826 \\
\hline & $\begin{array}{l}\text { SNO4: Most of the people I consult with think that I } \\
\text { should write referrals on Facebook }\end{array}$ & & .676 & .838 \\
\hline & $\begin{array}{l}\text { SNO5: Many of my important relatives and friends } \\
\text { write referrals on Facebook }\end{array}$ & & .655 & .842 \\
\hline \multirow{4}{*}{$\begin{array}{l}\text { Perceived } \\
\text { Behavioral } \\
\text { Control } \\
\text { (PEBC) }\end{array}$} & $\begin{array}{l}\text { PEBC1: I am confident to write write referrals on } \\
\text { Facebook }\end{array}$ & .859 & .658 & .839 \\
\hline & $\begin{array}{l}\text { PEBC2: I know well how to write referrals on } \\
\text { Facebook }\end{array}$ & & .762 & .797 \\
\hline & $\begin{array}{l}\text { PEBC3: I believe writing referrals on Facebook is } \\
\text { easy }\end{array}$ & & .714 & .817 \\
\hline & $\begin{array}{l}\text { PEBC4: I am fully qualified to write referrals on } \\
\text { Facebook }\end{array}$ & & .688 & .827 \\
\hline \multirow{5}{*}{$\begin{array}{l}\text { Ego } \\
\text { Involvement } \\
\quad \text { (EI) }\end{array}$} & $\begin{array}{l}\text { Write referrals on Facebook is an important part of } \\
\text { defining who I am }\end{array}$ & .903 & .697 & .895 \\
\hline & $\begin{array}{l}\text { EI1: Write referrals on Facebook is an important part } \\
\text { of my daily life }\end{array}$ & & .829 & .866 \\
\hline & $\begin{array}{l}\text { EI2: I'll be disappointed if I give up writing referrals } \\
\text { on Facebook }\end{array}$ & & .799 & .873 \\
\hline & $\begin{array}{l}\text { EI3: Write referrals on Facebook would be a good } \\
\text { way for me to express myself on social media }\end{array}$ & & .728 & .888 \\
\hline & $\begin{array}{l}\text { EI4: Write referrals on Facebook will be an } \\
\text { important way for me to brand my image on } \\
\text { Facebook }\end{array}$ & & .741 & .886 \\
\hline \multirow{5}{*}{$\begin{array}{l}\text { Awareness of } \\
\text { Consequence } \\
\quad(\text { AC) }\end{array}$} & $\begin{array}{l}\text { AC1: No write referrals on Facebook can cause } \\
\text { negative consequences for others when making a } \\
\text { purchase }\end{array}$ & .894 & .707 & .879 \\
\hline & $\begin{array}{l}\text { AC2: No write referrals on Facebook can make the } \\
\text { spread of fake referrals on Facebook more serious }\end{array}$ & & .723 & .875 \\
\hline & $\begin{array}{l}\text { AC3: No social referral reduces the contribution of } \\
\text { useful information to the community }\end{array}$ & & .733 & .873 \\
\hline & $\begin{array}{l}\text { AC4: No write referrals on Facebook can reduce the } \\
\text { overall benefit of the social network community }\end{array}$ & & .784 & .862 \\
\hline & $\begin{array}{l}\text { AC5: No write referrals on Facebook can cause } \\
\text { negative consequences for the community }\end{array}$ & & .763 & .867 \\
\hline \multirow{2}{*}{$\begin{array}{l}\text { Ascription of } \\
\text { Responsibility } \\
\text { (AR) }\end{array}$} & $\begin{array}{l}\text { AR1: I feel responsible for other people's wrong } \\
\text { buying decisions for not doing social referrals }\end{array}$ & .918 & .758 & .907 \\
\hline & $\begin{array}{l}\text { AR2: I feel responsible for doing write referrals on } \\
\text { Facebook because there are many fake referrals } \\
\text { going viral on facebook }\end{array}$ & & .743 & .909 \\
\hline
\end{tabular}




\begin{tabular}{|c|c|c|c|c|}
\hline & $\begin{array}{l}\text { AR3: I feel partly responsible for not contributing } \\
\text { useful information to the community by not social } \\
\text { referring }\end{array}$ & & .809 & .896 \\
\hline & $\begin{array}{l}\text { AR4: I feel responsible for the negative } \\
\text { consequences for others and for the community }\end{array}$ & & .830 & .891 \\
\hline & $\begin{array}{l}\text { AR5: I feel partly responsible for reducing common } \\
\text { interests of social networking community because of } \\
\text { not social referring }\end{array}$ & & .811 & .895 \\
\hline \multirow{5}{*}{$\begin{array}{l}\text { Intention of } \\
\text { Write } \\
\text { Referrals on } \\
\text { Facebook } \\
\text { (INWR) }\end{array}$} & $\begin{array}{l}\text { INWR1: I intend to introduce social in the near } \\
\text { future }\end{array}$ & .888 & .699 & .870 \\
\hline & INWR2: I plan to introduce social in the near future & & .749 & .859 \\
\hline & $\begin{array}{l}\text { INWR3: I am willing to expend my time and effort } \\
\text { on social referring in the future }\end{array}$ & & .759 & .856 \\
\hline & $\begin{array}{l}\text { INWR4: I will do write referrals on Facebook } \\
\text { whenever I can }\end{array}$ & & .726 & .864 \\
\hline & INWR5: I will suggest others to write social referrals & & .707 & .868 \\
\hline
\end{tabular}

\subsection{Exploratory Factor Analysis (EFA)}

The results of EFA of independent variables (Table 3) showed that the KMO coefficient reached $0.954(0.5<$ $\mathrm{KMO}<1)$ and the $\mathrm{Sig}=0.000(<0.05)$. At the value of Eigenvalue $=1,058(>1)$, factor analysis has extracted 6 factors from 29 items with total variance explained reached $70.483 \%$ (greater than 50\%). These six factors explain $70.483 \%$ of the variability of the data. The loading of all items isgreater than 0.5. (Table 3). For

Table 3: EFA for independent variables.

\begin{tabular}{|c|c|c|c|c|c|c|}
\hline \multirow{2}{*}{ Item } & \multicolumn{7}{|c|}{ Factor } \\
\hline & $\mathbf{1}$ & $\mathbf{2}$ & $\mathbf{3}$ & $\mathbf{4}$ & $\mathbf{5}$ & $\mathbf{6}$ \\
\hline AR3 & .754 & & & & & \\
\hline AR5 & .717 & & & & & \\
\hline AR4 & .706 & & & & & \\
\hline AR1 & .651 & & & & & \\
\hline AR2 & .633 & & & & & \\
\hline ATT2 & & & .714 & & & \\
\hline ATT4 & & & .701 & & & \\
\hline ATT5 & & & .683 & & & \\
\hline EI1 & & & & .740 & & \\
\hline EI2 & & & & .701 & & \\
\hline EI3 & & & & .673 & & \\
\hline EI5 & & & & .648 & & \\
\hline EI4 & & & & .640 & & \\
\hline SNO2 & & & & & .695 & \\
\hline SNO3 & & & & & .641 & \\
\hline SNO1 & & & & & .640 & \\
\hline SNO4 & & & & & .618 & \\
\hline
\end{tabular}

Table 4: EFA for dependent variable

\begin{tabular}{|c|c|c|}
\hline Construct & Item & Factor \\
\hline Intention of & INWR1 & .854 \\
\hline
\end{tabular}

dependent variable (INWR), five items have all loadings greater than $0,5(0.854 ; 0.847 ; 0.830 ; 0.816 ; 0.808)$. KMO test results are $0.871>0.5$ with Sig. $=0.000(<0.05)$; Eigenvalue coefficient $=3.454(>1)$, total variance extracted $69.071 \%$ (Table 4 ). From these results of EFA, the research scale ensures convergent and discriminant validity. All items fit the study data and were all retained for regression analysis.

\begin{tabular}{|c|l|l|l|l|l|l|}
\hline AC2 & & .749 & & & & \\
\hline AC3 & & .725 & & & & \\
\hline AC1 & & .719 & & & & \\
\hline AC4 & & .693 & & & & \\
\hline AC5 & & .650 & & & & \\
\hline ATT3 & & & .789 & & & \\
\hline AT1 & & & .749 & & & \\
\hline
\end{tabular}

\begin{tabular}{|c|c|c|c|c|c|c|}
\hline SN5 & & & & & .577 & \\
\hline PEBC2 & & & & & & .773 \\
\hline PEBC3 & & & & & & .655 \\
\hline PEBC4 & & & & & & .652 \\
\hline PEBC1 & & & & & & .644 \\
\hline \multicolumn{5}{|c|}{ Total Variance Explained (\%) } & 70.483 \\
\hline \multicolumn{5}{|c|}{ Adequacy } \\
\hline \multicolumn{5}{|c|}{ Kaiser-Meyer-Olkin Measure of Sampling } & .954 \\
\hline \multicolumn{5}{|c|}{ Approx. } & 10552. \\
Chi-Square & 679 \\
\hline
\end{tabular}

\begin{tabular}{|c|c|c|}
\hline $\begin{array}{c}\text { Write } \\
\text { Referrals on }\end{array}$ & INWR2 & .847 \\
\cline { 2 - 3 } & INWR3 & .830 \\
\hline
\end{tabular}




\begin{tabular}{|c|c|c|c|}
\hline \multirow{2}{*}{$\begin{array}{l}\text { Facebook } \\
\text { (INWR) }\end{array}$} & INWR4 & \multicolumn{2}{|l|}{.816} \\
\hline & INWR5 & \multicolumn{2}{|l|}{.808} \\
\hline \multicolumn{3}{|c|}{ Total Variance Explained (\%) } & 69.071 \\
\hline \multicolumn{3}{|c|}{$\begin{array}{l}\text { Kaiser-Meyer-Olkin Measure of Sampling } \\
\text { Adequacy. }\end{array}$} & .871 \\
\hline
\end{tabular}

\subsection{Pearson correlation analysis}

Before conducting multiple linear regression analysis, the Pearson correlation analysis is performed to examine the correlation between the independent variables with the dependent variable and between the independent variables in the research model.

The results show that the variables are correlated with each other, six independent variables are correlated with the dependent variable. In which, INWR has the highest correlation with AR $(r=0.742)$ and weakest with ATT ( $r$ $=0.500)$. All of six independent variables ATT, SNO, PEBC, AC, AR, EI have Sig=0.000 $<0.05$ (Table 5). Thus, it can be concluded that 6 independent variables can be included in the model to explain the dependent variable INWR. In addition, the correlation coefficient between the independent variables is also quite high. Therefore, multicollinearity test should be performed in the next steps to determine whether the independent variables influence each other.

\subsection{Regression analysis}

To measure the intention of Vietnamese consumers to write referrals on Facebook, the study implements a regression analysis of six independent factors and the dependent variable by using the methode Enter. The table 6 presents the multiple linear regression model Table 5: Results of Pearson's correlation analysis

\begin{tabular}{|c|c|c|}
\hline \multirow{4}{*}{ Bartlett's Test of Sphericity } & $\begin{array}{c}\text { Approx. } \\
\text { Chi-Square }\end{array}$ & 1324.560 \\
\cline { 2 - 3 } & df & 10 \\
\cline { 2 - 3 } & Sig. & .000 \\
\hline
\end{tabular}

summary and overall fit statistics. Results show that the adjusted $\mathrm{R}^{2}$ of model is 0.632 with the $\mathrm{R}^{2}=0.636$. Thus, the linear regression explains $63.6 \%$ of the variation of data. The The Durbin-Watson $\mathrm{d}=1.944$, which is between the two critical values of $1.5<\mathrm{d}<2.5$ (Table 6). Thus, there is no first order linear auto-correlation in multiple linear regression data of this study.

Table 6: Model summary ${ }^{\text {b }}$

\begin{tabular}{|l|c|c|c|c|c|}
\hline & & & Adjusted & Std.error & Durbin \\
Model & $\mathrm{R}$ & $\mathrm{R}^{2}$ & $\mathrm{R}^{2}$ & & Watson \\
\hline 1 & $.798^{\mathrm{a}}$ & .636 & .632 & .43143 & 1.944 \\
\hline
\end{tabular}

Table 7: Results of ANOVA analysis and F test

\begin{tabular}{|c|c|c|c|c|c|c|}
\hline \multicolumn{2}{|c}{ Model } & $\begin{array}{c}\text { Sum of } \\
\text { squares }\end{array}$ & df & $\begin{array}{r}\text { Mean } \\
\text { square }\end{array}$ & F & Sig. \\
\hline \multirow{4}{*}{1} & Regression & 162.105 & 6 & 27.017 & 145.150 & $.000^{\mathrm{b}}$ \\
\cline { 2 - 7 } & Residual & 92.695 & 498 & .186 & & \\
\cline { 2 - 8 } & Total & 254.800 & 504 & & & \\
\hline
\end{tabular}

\begin{tabular}{|c|c|c|c|c|c|c|c|c|}
\hline & & ATT & SNO & PEBC & EI & $\mathrm{AC}$ & INWR & $\mathbf{A R}$ \\
\hline \multirow{3}{*}{ ATT } & $\begin{array}{c}\text { Pearson } \\
\text { Correlation }\end{array}$ & 1 & $.626^{* *}$ & $.584^{* *}$ & $.454^{* *}$ & $.511^{* *}$ & $.500^{* *}$ & $.488^{* *}$ \\
\hline & Sig. (2-tailed) & & .000 & .000 & .000 & .000 & .000 & .000 \\
\hline & $\mathrm{N}$ & 505 & 505 & 505 & 505 & 505 & 505 & 505 \\
\hline \multirow[t]{3}{*}{ SNO } & $\begin{array}{c}\text { Pearson } \\
\text { Correlation }\end{array}$ & $.626^{* *}$ & 1 & $.714^{* *}$ & $.667^{* *}$ & $.643^{* *}$ & $.665^{* *}$ & $.676^{* *}$ \\
\hline & Sig. (2-tailed) & .000 & & .000 & .000 & .000 & .000 & .000 \\
\hline & $\mathrm{N}$ & 505 & 505 & 505 & 505 & 505 & 505 & 505 \\
\hline \multirow{3}{*}{ РEBC } & $\begin{array}{c}\text { Pearson } \\
\text { Correlation }\end{array}$ & $.584^{* *}$ & $.714^{* *}$ & 1 & $.644^{* *}$ & $.617^{* *}$ & $.635^{* *}$ & $.651^{* *}$ \\
\hline & Sig. (2-tailed) & .000 & .000 & & .000 & .000 & .000 & .000 \\
\hline & $\mathrm{N}$ & 505 & 505 & 505 & 505 & 505 & 505 & 505 \\
\hline \multirow{3}{*}{ EI } & $\begin{array}{c}\text { Pearson } \\
\text { Correlation }\end{array}$ & $.454^{* *}$ & $.667^{* *}$ & $.644^{* *}$ & 1 & $.685^{* *}$ & $.710^{* *}$ & $.763^{* *}$ \\
\hline & Sig. (2-tailed) & .000 & .000 & .000 & & .000 & .000 & .000 \\
\hline & $\mathrm{N}$ & 505 & 505 & 505 & 505 & 505 & 505 & 505 \\
\hline \multirow{2}{*}{$\mathbf{A C}$} & $\begin{array}{c}\text { Pearson } \\
\text { Correlation }\end{array}$ & $.511^{* *}$ & $.643^{* *}$ & $.617^{* *}$ & $.685^{* *}$ & 1 & $.647^{* *}$ & $.720^{* *}$ \\
\hline & Sig. (2-tailed) & .000 & .000 & .000 & .000 & & .000 & .000 \\
\hline
\end{tabular}




\begin{tabular}{|c|c|c|c|c|c|c|c|c|}
\hline & $\mathrm{N}$ & 505 & 505 & 505 & 505 & 505 & 505 & 505 \\
\hline \multirow{3}{*}{ INWR } & $\begin{array}{c}\text { Pearson } \\
\text { Correlation }\end{array}$ & $.500^{* *}$ & $.665^{* *}$ & $.635^{* *}$ & $.710^{* *}$ & $.647^{* *}$ & 1 & $.742^{* *}$ \\
\hline & Sig. (2-tailed) & .000 & .000 & .000 & .000 & .000 & & .000 \\
\hline & $\mathrm{N}$ & 505 & 505 & 505 & 505 & 505 & 505 & 505 \\
\hline \multirow{3}{*}{$\mathbf{A R}$} & $\begin{array}{c}\text { Pearson } \\
\text { Correlation }\end{array}$ & $.488^{* *}$ & $.676^{* *}$ & $.651^{* *}$ & $.763^{* *}$ & $.720^{* *}$ & $.742^{* *}$ & 1 \\
\hline & Sig. (2-tailed) & .000 & .000 & .000 & .000 & .000 & .000 & \\
\hline & $\mathrm{N}$ & 505 & 505 & 505 & 505 & 505 & 505 & 505 \\
\hline
\end{tabular}

**. Correlation is significant at the 0.01 level (2-tailed).

The results of ANOVA analysis and $\mathrm{F}$ test (Table 7) show that with Sig. $=0.000(<0.05)$, the sum of squares of the regression (162.105) is greater than the sum of squares of the residuals $(92,695)$. It means that the model explains a significant amount of the variance of the dependent variable (INWR). This proves that the linear regression model is suitable for the research data.

Table 8 shows results of hypothesies and multicollinearity tests of multiple linear regression model. The maximum value of VIF is 3.132 (10). There is no multicollinearity. Therefore, the relationship between the independent variables does not significantly affect the explanatory results of the regression model. As shown in table 8, out of 6 factors, only 4 factors (SNO, PEBC, AR and AR) are significant predictors $(\mathrm{Sig}<0,05)$. It can be seen that AR has a highest impact on intention to write referrals on Facebook with the standardized coefficients Beta $=0,331$, higher than EI $($ Beta $=0,225)$, SNO $($ Beta $=0,139)$ and PEBC $($ Beta $=$
0.095). Thus, hypothesies $\mathrm{H} 2, \mathrm{H} 3, \mathrm{H} 4, \mathrm{H} 6$ are all supported. The two hypothesies $\mathrm{H} 1$ and $\mathrm{H} 5$ were rejected (Sig.>0.05). The linear regression equation according to the standardized Beta coefficient is as follows:

\section{INSR $=0.581+0.095 * \mathrm{PEBC}+0.225 * \mathrm{AR}+0.331 * \mathrm{EI}+0.139 * \mathrm{SNO}$}

\section{CONCLUSION}

Miao and Wei (2013) suggested that it is important to examine people's pro-social behavior in different settings due to the critical contextual influence on their behavioral patterns. This study has examined writing referrals on Facebook as a pro-social behavior. That could be a new approach that has never been mentionned in previous studies. In addtion, the literature review also shows that there has not been a study to build and test a research model with predictors of pro-social behavior for the study of intention to write referrals in general and to write referrals on Facebook in particular.

Table 8: Results of the multiple linear regression analysis

\begin{tabular}{|c|c|c|c|c|c|c|c|c|}
\hline \multicolumn{2}{|r|}{ Model } & $\begin{array}{l}\text { Unstandardized } \\
\text { Coefficients }\end{array}$ & $\begin{array}{l}\text { Standardized } \\
\text { Coefficients }\end{array}$ & $\mathrm{t}$ & Sig. & VIF & \multirow[t]{2}{*}{ Hypothesis } & \\
\hline \multirow{5}{*}{1} & Constant & .581 & & 4.273 & .000 & & & \\
\hline & ATT & .061 & .053 & 1.478 & .140 & 1.789 & $\begin{array}{l}\text { H1: Attitude }(A T T) \text { is } \\
\text { positively related to } \\
\text { intention to write } \\
\text { referrals on Facebook } \\
\text { (INWR) }\end{array}$ & Non-Supported \\
\hline & PEBC & .100 & .095 & 2.208 & .028 & 2.511 & $\begin{array}{l}\text { H3: Perceived } \\
\text { behavioral control } \\
\text { (PEBC) is positively } \\
\text { related to intention to } \\
\text { write referrals on } \\
\text { Facebook (INWR) }\end{array}$ & Supported \\
\hline & EI & 188 & .225 & 4.914 & .000 & 2.880 & $\begin{array}{l}\text { H4: Ego involvement } \\
\text { (EI) is positively } \\
\text { related to intention to } \\
\text { write referrals on } \\
\text { Facebook (INWR) }\end{array}$ & Supported \\
\hline & $\mathrm{AC}$ & .077 & .079 & 1.860 & .064 & 2.492 & $\begin{array}{l}\text { H5: Consequence } \\
\text { perception } \quad(A C) \text { is }\end{array}$ & Non-Supported \\
\hline
\end{tabular}




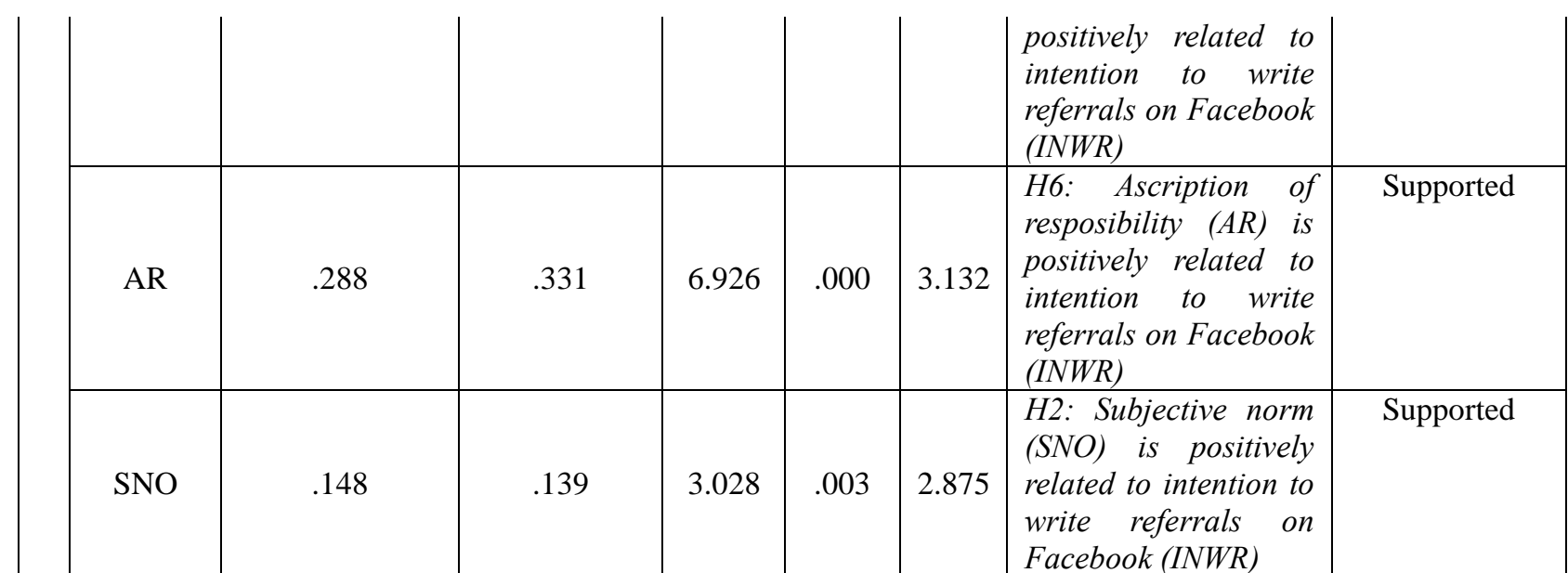

The proposed research model in this study is an attempt to provide a more comprehensive understanding of vietnamese consumers' intention of writing referrals on Facebook. By combining the study of factors belonging to two typical basic theoretical models TPB and NAM, adding the factor Ego involvement, this study has proved that part of the proposed model can be applied to predict vietnamese consumers' intention to write referrals on Facebook. This study has discovered some of internal factors that influence the intention to write referrals on Facebook, including factors that explain individual and social motivation. Out of 6 hypothesized predictors in the theoretical study, only four have been shown to have a positive impact on the intention to write referrals on Facebook of Vietnamese consumers. These are the factors: ascription of responsibility (social motivation), subjective norm, perceived behavioral control, and ego involvement (individual motivation). And ascription of responsibility has the highest impact. It suggests that Vietnamese consumers tend to be responsible for the consequences of not performing writing referrals on Facebook. Futhermore, the results also mentionned a significant impact of ego involvement on the intention to write referrals. It means that people high on ego involvement were more likely to write referrals on Facebook. In addition, people are also affected by factors of social pressure (subjective norm) as well as individual perceptions and understandings about writing referrals on Facebook (perceived behavioral control). People with a high level of subjective norm and perceived behavioral control are more likely to have an intention to write referrals on Facebook. With these results, this study provides some important pratical and managerial implications for managers.

From a practical standpoint, identifying the factors afftecting consumers' intention to write referrals on Facebook is beneficial for business managers especially for their development of marketing strategies. Businesses that aim to increase sales and their brand, need to carefully understand some customer characteristics such as the tendency of ascription of responsibility for consequences from fake referrals, the influence of social pressure or tendency to express their ego,... From there, businesses build marketing strategies, motivate consumers to write referrals about their products/services or brand. This study shows that ascription of responsibility and ego involvement are the prominent factors that have the biggest impact on consumers' intention to write referrals on Facebook. Therefore, marketing strategists need to prioritize creating favorable conditions to promote this tendency of ascription of responsibility as well as the ego involvement of their customers.

Besides, subjective norm also positively affect the intention to write referrals of consumers. Therefore, marketers target not only their potential customers but also their important reference groups in their marketing strategy. The results show the last construct that significantly affects the intention to write referrals on Facebook is percieved behavioral control. As perceived behavioral control was identified as an important predictor of writing referrals, managers could not only promote writing referrals but also simplify writing referrals process for their customer. That could help their customers be more confident when writing referrals about products/services and brands for the business.

The present study has a some limitations. This study only focused on writing referrals on Facebook without considering other popular social media platforms in Vietnam such as Zalo, Youtube,...Future researchers can check these results on other social media platforms. A comparative study between writing referrals on social media and on other online platforms (e.g. e-commerce platforms, review platforms, ..) could be an interesting research direction in the future. In addition, future studies may not only study the intention to write referrals in general, but also study this intention to write referrals for a specific industry. Future research can carry out comparative studies between different industries or can add many other factors such as social responsibility, previous experiences,....

Another important limitation of the study is that the study only focuses on evaluating the direct relationship between the independent variables and the intention to write referrals on Facebook. In the future, the indirect role (mediator, regulator, control) of the variables can be 
included in the study. In addition, this study also lacks demographic variables, which can have role as control variables in the model to help more comprehensive understanding of Vietnamese consumers' intention to write referrals on Facebook. This may be supplemented in further studies. The study also has a limitation when using survey method in data collection. In the future, researchers can perform empirical studies and explore relationships between dependent and independent variables in different experimental contexts.

\section{ACKNOWLEDGMENTS}

The authors would like to acknowledge the contributions of the training experts, interviewees who participated in the interviews as well as those who answered the questionnaires; friends and colleagues who provided helpful suggestions to help the authors complete this study.

\section{REFERENCES}

[1] Ajzen, I., (1985). From intentions to actions: A theory of planned behavior. In: Kuhl, J., Beskmann, J. (Eds.), Action control: From cognition to behavior. Springer-Verlag, NewYork, pp. 11-39.

[2] Ajzen, I. (1991) "The theory of planned behavior", Organizational Behavior and Human Decision Processes, 50(2), pp. 179-211.

[3] Bandura, A. (1997). Self-efficacy: The exercise of control. New York: Freeman.

[4] Buffardi, L. E., và Campbell, W. K. (2008). Narcissism and social networking web sites. Personality and social psychology bulletin, 34(10), pp.1303-1314

[5] Cakim, I.M. (2009) Implementing Word of Mouth Marketing: Online Strategies to Identify Influencers, Craft Stories, and Draw Customers. John Wiley \& Sons.

[6] Cheng, S., Lam, T., Hsu, C.H. (2006). Negative word-of-mouth communication intention: an application of the theory of planned behavior. . Journal of Hospitality và Tourism Research, 30(1), pp.95-116.

[7] Cheshire, C. (2007). Selective incentives and generalized information exchange. Social Psychology Quarterly, 70(1), pp. 82-100.

[8] Conner, M., Warren, R., Close, S., Sparks, P., 1999. Alcohol consumption and the theory of planned behavior: an examination of the cognitive mediation of past behavior. J. Appl. Soc. Psychol. 29, pp.16761704.

[9] De Groot, J.I., Steg, L., 2009. Morality and prosocial behavior: the role of awareness, responsibility, and norm in the norm activation model. J. Soc. Psychol. 149 (4), pp.425-449.
[10] Dixit, S., Badgaiyan, A.J., 2016. Towards improved understanding of reverse logisticsExamining mediating role of return intention. Resour. Conserv. Recycling,107, pp. 115-128.

[11] Fishbein, M., (1979). A Theory of Reasoned Action: Some Applications and Implications.

[12] Fishbein, M. and Ajzen, I. (1975) Belief, Attitude, Intention and Behaviour: An Introduction to Theory and Research. Reading, MA: Addison-Wesley.

[13] Fogel, J., Zachariah, S., (2017). Intentions to Use the Yelp Review Website and Purchase Behavior after Reading Reviews. J. Theor. Appl. Electron. Commerce Res. 12 (1), pp.53-67.

[14] Han, H., (2014). The norm activation model and theory-broadening: individuals' decision- making on environmentally - responsible convention attendance. J. Environ. Psychol. 40, 462-471.

[15] Han, H., Lee, M.J., Hwang, J., (2016). Cruise travelers' environmentally responsible decision-making: an integrative framework of goal-directed behavior and norm activation process. Int. J. Hosp. Manage. 53, 94-105.

[16] Harland, P., Staats, H., Wilke, H.A., (2007). Situational and personality factors as direct or personal norm mediated predictors of pro-environmental behavior: questions derived from norm-activation theory. Basic Appl. Soc. Psychol. 29 (4), pp.323-334.

[17] Hennig-Thurau, T., Gwinner, K.P., Gremler, D.D., (2002). Understanding relationship marketing outcomes an integration of relational benefits and relationship quality. J. Serv. Res. 4 (3), pp.230-247.

[18] Hoàng Trọng, Chu Nguyễn Mộng Ngọc (2008), Phân tích dữ liệu nghiên cứu với SPSS, NXB Hồng Đức 2008.

[19] Huang, M., Cai, F., Tsang, A.S.L. and Zhou, N. (2011) "Making your online voice loud: the critical role of WOM information", European Journal of Marketing, 45(7-8), pp. 1277-1297

[20] Jalilvand, M.R., Samiei, N., (2012). The impact of electronic word of mouth on a tourism destination choice: testing the theory of planned behavior (TPB). Int. Res.: Electron. Netw. Appl. Policy 22 (5), pp.591-612.

[21] Kim, N; Kim, W. (2018). Do your social media lead you to make social deal purchases? Consumer-generated social referrals for sales via social commerce. International Journal of Information Management, 39, pp. 38-48.

[22] Lapinski, M.K., Rimal, R.N. (2005). An explication of social norm . . Communication Theory , 15(2), pp.127-147.

[23] Nambisan, S. and Baron, R.A. (2007) "Interactions in virtual customer environments: 
Implications for product support and customer relationship management", Journal of Interactive Marketing, 21(2), pp. 42-62.

[24] Nunnally, J. C. (1978). Psychometric theory. New York, NY: McGraw-Hill.

[25] Park, N., Oh, H.S., Kang, N., (2015). Effects of ego involvement and social norm on in- dividuals uploading intention on Wikipedia: a comparative study between the United States and South Korea. J. Assoc. Inf. Sci. Technol. 66 (7), pp.1494-1506.

[26] Perloff, R.M., 1989. Ego-involvement and the third person effect of televised news cov- erage. Commun. Res. 16 (2), pp.236-262.

[27] Picazo-Vela, S., Chou, S.Y., Melcher, A.J., Pearson, J.M., 2010. Why provide an online review? An extended theory of planned behavior and the role of Big-Five personality traits. Comput. Hum. Behav. 26 (4), pp.685-696.

[28] Ryan, T., và Xenos, S. . (2011). Who uses Facebook? An investigation into the relationship between the Big Five, shyness, narcissism, loneliness, and Facebook usage. . Computers in Human Behavior, 27(5), pp.1658-1664.

[29] Schwartz, S. H. (1973). Normative explanations of helping behavior: A critique, proposal, and empirical test. Journal of Experimental Social Psychology, 9, pp.349-364.

[30] Schwartz, S. H. (1977). Normative influences on altruism. In L. Berkowitz (Ed.), Advances in experimental social psychology (Vol. 10). New York: Academic Press.

[31] Schwartz, S. H., \& Clausen, G. T. (1970). Responsibility, norm, and helping in an emergency. Journal of Personality and Social Psychology, 16, pp.299-310.

[32] Schwartz, S. H., \& David, A. B. (1976). Responsibility and helping in an emergency: Effects of blame, ability and denial of responsibility. Sociometry, 39, pp. 406-415.

[33] Schwartz, S. H., \& Fleishman, J. A. (1982). Effects of negative personal norm on helping behavior. Personality and Social Psychology Bulletin, 8, pp.81-86.

[34] Schwartz, S. H., \& Howard, J. A. (1980). Explanations of the moderating effect of responsibility denial on the personal norm-behavior relationship. Social Psychology Quarterly, 43, pp.441-446.

[35] Schwartz, S. H., \& Howard, J. A. (1981). A normative decision-making model of altruism. In J. P. Rushton \& R. M. Sorrentino (Eds.), Altruism and helping behavior (pp. 89-211). Hillsdale: Erlbaum.

[36] Sherif, C. W., Kelly, M., Rodgers, H. L., Sarup, G., \& Tittler, B. I. (1973). Personal involvement, social judgment, and action. Journal of Personality and Social Psychology, 27, pp.311-328.

[37] Sorensen, A.T. và Rasmussen, S.J. (2004). Is any publicity good publicity? A note on the impact of book reviews. NBER Working paper.

[38] Steg, L., de Groot, J., 2010. Explaining prosocial intentions: testing causal relationships in the norm activation model. Br. J. Soc. Psychol. 49 (4), pp.725743.

[39] Stern, P.C. (2000). Towards a coherent theory of environmentally significant behavior. Journal of Social Issues, 56, pp.407-424.

[40] Tyler, T. R., Orwin, R., \& Schurer, L. (1982). Defensive denial and high cost prosocial behavior. Basic and Applied Social Psychology, 3, pp.267-281.

[41] Wang, P., (2014), November. Understanding the influence of electronic word-of-mouth on outbound tourists' visit intention. In Conference on e-Business, e-Services and e- society Springer Berlin Heidelberg. pp. 33-45.

[42] Wang, X., Yu, C. and Wei, Y. (2012) "Social Media Peer Communication and Impacts on Purchase Intentions: A Consumer Socialization Framework", Journal of Interactive Marketing, 26(4), pp. 198-208.

[43] Wu, J. M. L., Tsai, H., và Lee, J. S. (2017). Unraveling public support for casino gaming: The case of a casino referendum in Penghu. Journal of Travel \& Tourism Marketing, 34(3), pp.398-415.

[44] Yan Kong, Yichuan Wang, Sam Hajli, Mauricio Featherman. (2019). In Sharing Economy We Trust: Examining the Effect of Social and Technical Enablers on Millennials' Trust in Sharing Commerce. Computers in Human Behavior, 11.

[45] Zhang, Y., Wang, Z., Zhou, G., . (2013). Antecedents of employee electricity saving behavior in organizations: an empirical study based on norm activation model. Energy Policy, pp.1120-1127 